\title{
Breast Cancer pNo(i+) TNM Finding v6
}

National Cancer Institute

\section{Source}

National Cancer Institute. Breast Cancer pNO(i+) TNM Finding v6. NCI Thesaurus. Code C48993.

Breast cancer without histological evidence of regional lymph node involvement, and positive morphologic findings for isolated tumor cells (ITCS) using any morphologic technique (including hematoxylin-eosin and/or immunohistochemistry), and no ITC cluster greater than $0.2 \mathrm{~mm}$. (from AJCC 6th Ed.) 